\title{
"AVENGE US NOT!" FORGIVENESS AND THE LOVE OF ENEMIES IN THE COMMUNIST PRISONS OF ROMANIA
}

\section{Grigorie BENEA*}

\begin{abstract}
The $20^{\text {th }}$ century was certainly the bloodiest century in all human history, witnessing more suffering, death, martyrdom and genocide than any other century before it. The suffering was intense and took many forms. My paper will attempt to present one aspect of this suffering, as it manifested itself in the communist prisons of Romania: the forgiveness and love of enemies, which in my view is characteristic of the martyrdom in the communist prisons, defining and proving its Christian character.

The main idea underlining the paper will be that forgiving the enemies was one of the most important means of transfiguring the unjust suffering and of healing the psychological traumas left by the savage experience of detention. Another point I am trying to make is that in their approach, the new martyrs followed - sometimes explicitly, but more often implicitly - the teachings of the Gospel and of the Holy Fathers regarding forgiveness and love for one's enemies. Therefore, the method used will be that of continuously confronting and comparing different concrete examples from detention (taken either from memoirs or from personal interviews) with texts from Patristic literature.

A central figure in this Christian attitude towards suffering was played by Valeriu Gafencu and his group of "mystics" from Aiud, whose influence will be analyzed in the paper. Other themes discussed will be forgiving the former judges and prosecutors, conversion of the torturers through forgiveness and love shown by the martyrs, gratitude towards prosecutors, love for enemies as a gift of Holy Grace, but also as a consequence of human struggle, prayer for the enemies as a means of acquiring love, but also as an expression of it, forgetting the suffered wrongs etc.
\end{abstract}

* PhD, Rev., Hyierom., The 'Aristotle' University of Thessaloniki, Faculty of Orthodox Theology, Thesaloniki, Grece. 
Keywords: forgiveness of enemies, new martyrs, communist prisons, Romania, Holy Fathers

\section{Introduction}

Undoubtedly, the $20^{\text {th }}$ century was the bloodiest century in all human history, witnessing more suffering, more death, more martyrdom and more genocide than any other century before it. The suffering was intense and it took many forms. Here, I will present one aspect of this suffering, as it manifested itself in the communist prisons of Romania (1948-1964).

The words in the title of my paper belong to one of the people that suffered in communist Romania, the well-known Christian philosopher Mircea Vulcănescu, and were spoken a short time before his death in the prison of Aiud in 1952. Unfortunately, I would say, the problem now is not so much that anyone would avenge this suffering, but rather that it is largely forgotten and ignored. In this sense, the suffering associated with the communist prisons in Romania stands in stark contrast with other forms of suffering of the $20^{\text {th }}$ century, even though the quantity of pain experienced there was in no sense less than that experienced elsewhere. Nevertheless, though there is no real danger this suffering being avenged today, I think the words of Mircea Vulcănescu are important in that they reflect one essential characteristic of the martyrdom in the communist prisons of Romania: the forgiveness and love of enemies, which in my view defines and proves the Christian character of the suffering in the prisons. This will be the topic of my address.

\section{Forgiving enemies as a means of transfiguring unjust suffering}

I would like to start my presentation with the words of an American convert to Orthodoxy, which I think sum-up two main ways of taking on and dealing with pain. His words were the product of his acquaintance with Fr. George Calciu, one of the greatest Christian confessors in communist Romania. He says:

"Listening to Fr. Calciu, I was shocked by his attitude towards the experience of the prison, an experience that had consumed a quarter of his life and had destroyed so many souls. It then came to my mind the 
stark contrast between Fr. Calciu and Elie Wiesel, one of the best known survivors of the Holocaust, a writer and a laureate of the Nobel Prize. At that time I didn't even realize that Wiesel was also born in Romania. Upon reading Wiesel's work, The Night, you notice how the author's faith in God was profoundly shaken by the suffering of the prison. You would also experience feelings of compassion and pity for Wiesel and all those locked away with him, who were not able to find a purpose for their suffering. But listening to the words of Fr. George about the hideous and cruel experience of the prison - an experience which was no less trying than that of Wiesel - you were at awe at how this man, Fr. Calciu, carried nothing more of its trauma with him. He wasn't speaking with any impatient resentments of a deep pain, with any wrath, but neither did he speak of it in an unfeeling or mechanical way; rather, he was speaking simply, with a certain glow in his eyes and a natural and genuine smile on his face. And he was not doing this from a desire of making a name for himself, nor in order to attract the respect of others, rather he was simply sharing a miracle of the human soul inspired by the grace of God. Faced with this miracle, you are left to pity yourself on account of your not having even a small fraction of the faith of this man."

There were many things that contributed to this approach to suffering, to its transfiguration by means of the grace of God, to the contrast that the above words note. The main way through which this suffering was healed and became a life- and light-giving power, however, was the forgiveness of enemies. It is here that the main Christian character of the experience of the prisons lies. And it is important to note that this was not just an isolated example of some highly gifted spiritual individuals, but indeed a general line of Christian understanding and embracing of political detention in Romania. As Aspazia Oțel Petrescu puts it: "the torturers taught a whole generation of Romanians how to forgive their enemies"2. The gruesome experience itself proved decisive in pushing the detainees towards forgiveness and love, providing a unique opportunity for the acquiring of these two fundamental Christian virtues. For this, however, an intense spiritual

1 ***, Viața părintelui Gheorghe Calciu, Bucureşti, Christiana, 2007, p. 250.

2 Video interview taken by Fr. Moses of Oașa Monastery with Aspazia Oțel Petrescu [provided by the author]. 
struggle was necessary. One would need to undergo an inner process that sometimes took years to come to fruition (and not just during prison, but also afterwards, sometimes even until death). On this road of forgiveness and love of one's enemies, each progressed as much as he could, some more, some less, but because detention was usually assumed in a Christian sense, forgiveness and love constituted a goal and ideal for most of the detainees.

\section{Forgiving in the name of Christ}

Essential in shaping this Christian attitude towards suffering was the "mystical" group of Aiud, centered around Valeriu Gafencu, who embraced in a martyric sense the whole experience of incarceration and influenced a large part of the prisoners in doing so. "We must die as martyrs, without protesting," said Gafencu. "This is the high line - to suffer till the last drop of blood without hitting back, without insulting"3. Confronting his fellow inmates who sought revenge and claimed that standing up violently against Communism was the only solution to conquering evil, Valeriu maintained that:

"revenge belongs only to God; no one is allowed to make his own justice; the Christian forgives, the Christian places himself in the position of love, the only virtue that can bring peace, the only attitude that conquers and cannot be conquered. Strong voices stood up against this point of view, and Valeriu, trying to justify himself, became more and more alone. Despite this, however, he remained unwavering in his conviction, and with time many adhered to his views"4.

Indeed, the whole of Church literature reinforces the importance of forgiving and loving one's enemies, seeing this as the most fundamental and characteristic Christian virtue. In contemporary times, St. Silouan the Athonite has expressed this most eloquently, calling the love of enemies ,the criterion of true faith, of true communion with God, the sign of the authentic work of grace"s. This criterion of true

${ }^{3}$ See the file of Fr. Nicholas Grebenea, no. I 235977, volume 2, p. 40-49, at CNSAS (National Council for the Studying of the Archives of the Secret Police).

${ }^{4}$ Ioan IANOLIDE, Intoarcerea la Hristos. Document pentru o lume nouă, foreword: Fr. George Calciu, Bucharest, Holy Monastery Diaconeşti, Christiana, 2006, p. 46.

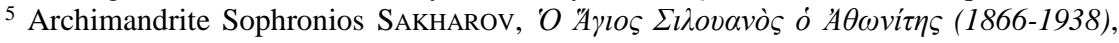


faith and of communion with God was widely and abundantly manifested in the communist prisons of Romania. In what follows, I will provide some examples, trying to highlight some central aspects of forgiveness and love for enemies as these manifested themselves in detention.

\section{Forgiving the former judges}

A first emblematic case was the detainees' forgiveness of the former judges that had convicted them and had ended up in prison afterwards. Many of the young prisoners belonging to the "mystical" group of Aiud had been imprisoned during World War II for political reasons and convicted for a large number of years, greatly exceeding their guilt and even their age for that matter. When the communists came to power in 1948, most of the former judges fell into disgrace and were thrown in prison. They were terrified at the prospect of being detained alongside the people they had previously unjustly prosecuted, expecting revenge. Fr. Nicholas Grebenea describes what eventually happened:

"They had their doors closed for fear we would barge in on them. They had no mattresses. Alecu Ghika sent his own straw mattress to judge Macici, and was left sleeping on the floor. It was a great surprise. [...] Mareş, the governor of the prison, told us: You have them here, they are your enemies. We don't prevent you from holding them accountable... But none of us took any action against them [...] Firstly because we were Christians and a lot of us had gone a long way in embracing Christianity. And there was also something else: an atmosphere of hell would have appeared among us [...]. We were all suffering now, we were all detainees and the same people were holding us in. We needed to show solidarity. Therefore we started not by killing or by persecuting them, but rather by helping them." 6

Fr. Grebenea himself writes how he gave his daily portion of milk to the judge who had condemned him to prison and who had fallen ill. The Holy Fathers teach that repaying those who have wronged you with

Holy Stavropegic Monastery of St. John the Forerunner, Essex, England, 1995, p. 153.

${ }^{6}$ Priest Nicolae GrebenEA, Amintiri din intuneric, Bucharest, Scara, 2000, p. 149-150. 
good constitutes a high degree of love for one's enemies. For example St. Maximus the Confessor says, "It is then that we reach love, when we can repay the bad with good, from an inner impulse" 7 . St. Isaac the Syrian exhorts in a similar manner: "Show the richness of your charity through the good with which you repay those that have wronged you"s.

But there were examples of people who took the helping of their former enemies to an even higher level, serving them with the highest degree of self-sacrifice. Such was the case of Nicholas Ţoţea, a young teacher arrested in 1941, who had developed a nervous disorder because of the tortures during the interrogations. When faced with his former judge, who was terrified that Țoţea would kill him in revenge, the young man not only helped him and gave him his daily portion of bread, but also took care of him when the judge fell ill, cleaning his worm-infested wounds and looking after him until his death as everyone else was disgusted even at his sight and smell ${ }^{9}$.

All this love generated real shock waves in the hearts of their enemies. At times, these were even touched to the point of changing their lives entirely. Forgiveness and love thus proved to be the instruments through which God wrought the spiritual resurrection of people not only foreign to the faith, but even adverse to it. The similarity with the lives of the ancient martyrs is obvious. Fr. Nicholas Steinhardt recounts one such case, that of a renowned socialist politician Ene Filipescu, a former ally of the communists who later ended up in jail:

“At Târgu-Ocna, a T.B. hospital of political detainees, Filipescu had proclaimed his atheist and socialist conviction in a room full of young legionaries. His disease was progressing fast and he grew ever sicker, suffering greatly until his death. The young legionaries treated him so kindly, so attentively, so full of abnegation and love, they showed him so much respect, that eventually they softened his heart. Before giving his last breath, Filipescu embraced the one that had been most devoted to him, then all others, confessed to Fr. Todea, and then passed away

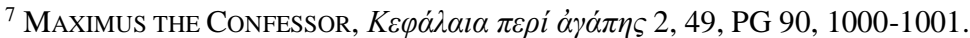

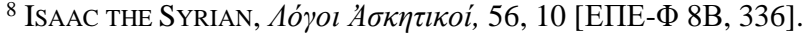

${ }^{9}$ Virgil MaXim, Imn pentru crucea purtată, $1^{\text {st }}$ vol., Timişoara, Gordian, 1997, p. 121.
} 
after having received Holy Communion." 10

\section{Gratitude towards persecutors}

Some of the prisoners advanced so far on the path towards loving their enemies that they not only forgave and helped those that had done them wrong, but even came to be thankful towards them; thankful because they had been given the opportunity to suffer for their faith in Christ; thankful for the opportunity to cleanse their sins; thankful for all the spiritual gifts the prison could bring to those who knew how to take advantage of it. Fr. Liviu Brânzaş notes characteristically:

"It is not for the first time that I have the conviction that we should love our persecutors most of all, for it is through them that the mystical will of God works, giving us the possibility - through the persecution we are subjected to - to accept and endure the unjust suffering. This moral attitude brings us closer to Christ." 11

This is in line with all the teachings of the patristic tradition regarding forgiving and being thankful to one's wrongdoers. Abba Zosimas, for example, writes: "If you should remember the one that had grieved or offended or harmed you, you should remember him as a doctor sent to you by Christ and consider him as one of your benefactors" $" 12$.

One such moving example from the prisons is that of Dr. Constantin Banu, who upon his release from prison went straight to his prosecutor to thank him.

"[Dr. Banu] had done many years in prison, and during this time his Christian feelings had deepened, becoming one with his behavior. $\mathrm{He}$ always used to pray to God for the judge that had convicted him, saying that because of his sentence he was now happy. [...] Upon getting out of jail, he didn't go first to his family, but rather straight to the house of his former unjust judge. I came here right away from jail, he said to the old retired man, to thank you. I am the one you convicted a long time ago, and I am grateful to you because in the prison you sent me, I found God! He then shook the hand of the panic-stricken judge. I am sure he thought

\footnotetext{
10 Nicolae SteInHARDT, Jurnalul fericirii, Cluj-Napoca, Dacia, 1991, p. 132-133.

${ }^{11}$ Liviu BrÂNZAȘ, Raza din catacombă, Bucharest, Scara, 2001, p. 277-278.

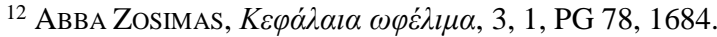


I was crazy, Dr. Banu said with a smile on his face, concluding his impressive story. [...] He had reached such a depth of Christian living, that he had acquired the gift of tears. When he was praying at the head of a dying person at Târgu Ocna, streams of tears would flow from his eyes as he besought God. This was not just a temporary amplification of his compassion for the suffering neighbor, but - as the Philokalia mentions - a divine gift, with which only some souls are endowed: the gift of tears." $" 13$

\section{Love for the enemies - a fruit and source of divine grace}

All these examples, show the authenticity and depth of spiritual life in communist prisons. Forgiving and helping those that have done you wrong, praying for them, even being grateful for their offences against you, are all signs of a rarely attained spiritual perfection. The love for one's enemies is the pinnacle of all Christian virtues and is in itself beyond the power of our fallen nature. It is first and foremost a fruit of the grace of the Holy Spirit, without which it is impossible to achieve. St. Silouan expresses this truth most eloquently, adding that the love for one's enemies is also witness to a great blessing of the grace of God: "Lord, You gave us the commandment to love our enemies, but this is toilsome for us, sinners, if your grace is not with us"14. And somewhere else: "When you will love your enemies, know that a great divine grace dwells within you" 15 .

These people who were able to forgive and love their enemies had in them, therefore, a great divine grace, which they had received through a life fully dedicated to Christ and sealed with great struggles and sufferings, even until death. More than that though, the love for the enemies was not just a sign of divine grace, it was also a source for God's blessing, because loving one's enemies is not just the work of God, it also implies a great spiritual struggle on the part of man himself. We have seen earlier how Dr. Banu had received the gift of tears as a crowning of his prayers and love for his prosecutor. The dimensions of the spiritual struggles the prisoners passed through in order to achieve

${ }^{13}$ Flor StRejnicu, Creștinismul Mișcării Legionare, Sibiu, Imago, 2001, p. 69-70.

${ }^{14}$ Archimandrite Sophronios SAKHAROV, op. cit., p. 47.

15 Ibidem, p. 130. 
forgiveness of enemies are shown by the example of Aspazia Oţel Petrescu. During one of her brutal interrogations, she was tied with her face down from the ceiling, and beaten cruelly over and over again. She was trying desperately not to scream and give any satisfaction to her torturers. At one point, the governor of the prison bowed down to see what was happening, intrigued by her silence. He saw her face contorted with pain, and this brought about a grin of satisfaction on his face. At that moment, Aspazia felt a surge of hate rushing into her soul. After the torture was over and she got back to her cell, her fellow inmates asked her in awe what had happened with her, since her face was so disfigured and riddled by hate. She realized what was going on and decided to keep a forty days fast, in the already austere conditions of detention, eating only her daily bread late in the afternoon, in order to be able to forgive that cruel governor. Only at the end of the fast did she feel her heart softening.

\section{Prayer for one's enemies - a fruit and source of love}

Such were the struggles the detainees had to perform in order to be able to forgive their wrongdoers. And as we've seen, God responded to these struggles by plentiful grace and blessing. We return again to St. Silouan, who says:

"It is a great thing before God that you pray for those that offend and grieve you. For this, the Lord will give you His grace, and you will know the Lord through the Holy Ghost and then you will suffer with joy all adversities for Him, and the Lord will give you the gift of loving the whole world and wishing arduously the good for all men and praying for all as for one soul." 16

Indeed, prayer for the enemies was perhaps the main tool the prisoners used in order to achieve forgiveness and love for them. Like with the holy grace, it both preceded and followed love. At first, one prays for his wrongdoers in order to keep his soul from harm, to fend off all the negative feelings that seek to penetrate his soul: grief, wrath, grudge, revengefulness, hate and all the rest. By this, he in fact protects himself, fights for the health of his own soul, for the power to forgive.

${ }^{16}$ Ibidem, p. 80. 
In these moments, one must force himself to a certain degree. One needs to push his heart to choose good and love, and not allow it to be seized by hatred; this pushing comes about mainly through prayer. It is by choosing to pray for the ones that did him wrong, that man shows his willingness to forgive and love. In itself, this is impossible to him, but God answers such a prayer and compensates for man's weakness with His own strength. Thus, little by little, forgiveness and love for the enemies are born in the soul. And the more one progresses in love, the more prayer flows from his heart naturally and spontaneously. Thus, prayer is no longer performed as a self-protection mechanism, but rather as a way of expressing love, as a means of beseeching God's mercy for the persons that are trapped by evil, so that God enlightens, helps and frees them from the paths of destruction they are on.

This was, in general, the experience of the prisons, not a theoretical, but a very practical and acute experience. Everything in prison demanded forgiveness; everything was an opportunity for prayer. We have already seen many references to this. We will add here one example of such prayer, taken from one of the leading figures of the "mystical" group of Aiud, Virgil Maxim. The young prisoners were repeating it each night before going to bed:

"Lord Jesus Christ, You who suffered for the whole mankind and forgave all those that repented for their sins, make none of those who hate and persecute us suffer any harm at Your judgment because of us. But rather turn their souls back to the knowledge of Truth and give them true repentance, that even through them Your most holy Name might be glorified. And make us worthy of confessing You, the true God, the Father, the Son and the Holy Spirit, for the glory of your name and for the salvation of our souls. Amen!"17

Such prayers were effective not only in the souls of those praying. When there was even the slightest good disposition on the part of the persecutors, prayer changed their hearts too, as so often happened in the lives of the ancient martyrs. Virgil Maxim also gives us one such example, when he prayed for a guardian that was brutally oppressing him, and he suddenly changed his attitude and was softened: "God had

${ }^{17}$ Virgil MАХIM, op. cit., p. 93. 
ARS LITURGICA. From the Image of Glory to the Images of the Idols of Modernity

arranged for this to happen for the salvation of his soul, assuring us that our prayers for our enemies were not in vain. [...] It was not once that I saw with my own eyes the miracle of both our and their salvation"18.

\section{Forgetting the wrongs}

A whole paper could be presented on the topic of the forgiveness of enemies within the context of the satanic experiment of the reeducation of Piteşti. Since there is no space for that here, however, I am going to end my lecture with the words of one that passed through the reeducation of Piteşti and with whom I have started my presentation, Fr. George Calciu. He took the virtue of forgiving his enemies to the extreme: the complete forgetting of wrongs that he suffered. The Holy Fathers themselves name forgetting the wrong as the highest degree of forgiving. St. Symeon the New Theologian writes: "The last step in forgiving is when one utterly forgets all that he suffered, not remembering any of the things that happened to him, either present or missing those that harmed him" ${ }^{19}$. Fr. Calciu experienced firsthand the need for forgiving and forgetting. Upon getting out of jail, he decided to write all that had happened to him, as a witness for men and for history. Something though started taking place in his soul. This is how he describes it:

"The more I wrote, the more my soul started to experience something new. It was like a movement of my heart that was bringing me suffering, some sort of disgust towards those people. I gradually realized that it was a beginning of hate. So I said to myself: I'm not writing anymore! I'm not going to remember anything! I had not yet read what Steinhardt says, that there is no forgiveness without forgetting. I said to myself that if I don't forget, it would be like they will be always in me and I will be their victim all over again. It was as if their spirits had become alive again and they were coming to torment me once more, but in a different way. I can now say that I forgot a whole lot. It might be that I also forget because of my old age, but anyway, I

18 Ibidem, p. 178.

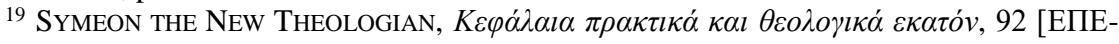
$\Phi$ 19, 450]. 
have forgotten a lot."20

\section{Conclusion}

In conclusion, I can say that forgiveness of enemies was an essential part of the suffering in communist prisons in Romania. If many of the detainees managed not only to remain spiritually unharmed by the savage experience of detention, but even to transfigure it into a lifegiving force, one that cleansed their souls and brought them closer to God, this was mainly due to their ability to forgive and love their enemies. Moreover, herein lays the main Christian character of the suffering in the prisons. Fr. Ioan Iovan describes how he was once brutally kicked in the back by a guard and fell to the ground. Getting up, he turned to the guard and said to him from the bottom of his heart: May God forgive you! "For the first time in my life," he concludes, "I felt I was truly a Christian and a priest."

\section{References}

1. ***, Viața părintelui Gheorghe Calciu, Bucharest, Christiana, 2007.

2. BRÂNZAŞ, Liviu, Raza din catacombă, Bucharest, Scara, 2001.

3. GReBEnEA, Nicolae, Amintiri din intuneric, Bucharest, Scara, 2000.

4. IANOLIDE, Ioan, Intoarcerea la Hristos. Document pentru o lume nouă, foreword: Fr. George Calciu, Holy Monastery Diaconeşti, Bucharest, Christiana, 2006.

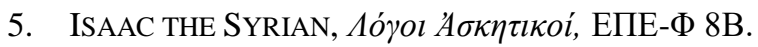

6. MAXIM, Virgil, Imn pentru crucea purtată, $1^{\text {st }}$ volume, Timişoara, Gordian.

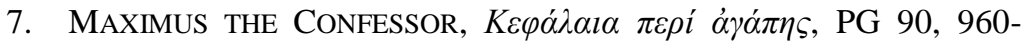
1080.

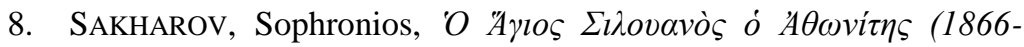
1938), Holy Stavropegic Monastery of St. John the Forerunner, Essex, England, 1995.

9. SteinhardT, Nicolae, Jurnalul fericirii, Cluj-Napoca, Dacia, 1991.

10. Strejnicu, Flor, Creștinismul Mișcării Legionare, Sibiu, Imago,

20 ***, Viața părintelui Gheorghe Calciu, p. 119. 
ARS LITURGICA. From the Image of Glory to the Images of the Idols of Modernity 2001.

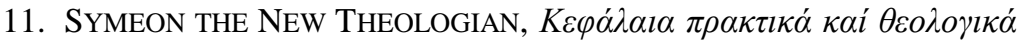

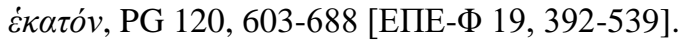

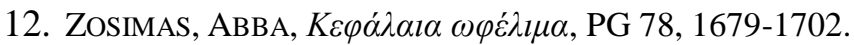

